\title{
Nutritional characteristics of cattle forage plants in the eutrophic nature reserve Oostvaardersplassen, Netherlands
}

\section{J. T. VULINK \& H. J. DROST}

Ministry of Transport and Public Works Directorate Flevoland, P.O. Box 600, NL 8200 AP Lelystad, Netherlands

Received 23 April 1991; accepted 30 September 1991

\begin{abstract}
The nutritional value of the main cattle forage plants was studied in the terrestrial part of the eutrophic wetland the Oostvaardersplassen, the Netherlands. The digestible organic matter (DOM) content and the chemical composition of the forage classes grasses, reed, forbs and browse varied seasonally. The DOM content of all forage classes showed a decrease from spring to winter as usual. However, the assumed minimum energy content for cattle maintenance (approximately $450 \mathrm{~g} \mathrm{DOM} \mathrm{kg}^{-1}$ dry matter) was reached at different moments in the different forage classes. Reed reached it in autumn, grasses in winter, forbs (living parts) remained the entire year above this level and browse remained the entire year below this level. Grazing delayed the maturation of Poa trivialis, reed (Phragmites australis) and the important forb Urtica dioica. The protein, K, Ca, P, Cu content of the four forage classes exceeded the cattle maintenance levels for these nutrients the whole year. The $\mathrm{Na}$ and $\mathrm{Mg}$ content of grasses, reed and browse were marginal in some periods of the year. Due to their high mineral contents, the forbs were an important mineral source in cattle diets. When compared with literature data from oligotrophic and mesotrophic habitats, the studied Poa-Phragmites eutrophic habitat offers comparable feed quality in spring, summer and autumn, but is inferior in winter.
\end{abstract}

Keywords: nature conservation, cattle forage, biochemical composition, digestibility, eutrophic wetland

\section{Introduction}

In the past twenty years grazing by free ranging cattle, horses, sheep and goates is increasingly used as a management technique in nature conservation in the Netherlands. Several hundreds of nature reserves (several thousands of ha) have been brought under a grazing regime. Partly this concerns semi-natural areas, which were formerly part of the agricultural system, but also parts of new landscapes (e.g. recently reclaimed polders) are managed this way.

The Oostvaardersplassen, 5600 ha in size, is an eutrophic wetland situated in the new polder South Flevoland, reclaimed in 1968, in the centre of the Netherlands $\left(52^{\circ} 26 \mathrm{~N}^{\prime}, 5^{\circ} 19^{\prime} \mathrm{O}\right)$. The marsh part of this nature reserve amounts to $3700 \mathrm{ha}$, the terrestrial part to 1900 ha. The soil fertility is high. Since emergence from the bot- 
tom of the fresh waterlake IJsselmeer, the vegetation of the Oostvaardersplassen developed rapidly by natural succession. Concurrently this area became an internationally important wetland for migrating waterfowl such as geese (Anser anser L., A. albifrons L.). However the rapid succession of the open grassy vegetation, important habitat for waterfowl, to dense stands of reed and willow (Salix spp.) was threatening to significantly reduce habitat suitability for waterfowl of the Oostvaardersplassen. For maintenance and further development of the ornithological values of this nature reserve, grazing by free ranging cattle and horses is being tried as a management tool.

As interference of man in ecosystem development has its examples of negative effects despite good intentions, it was decided to perform small scale experiments under controlled circumstances with free ranging cattle before introducing cattle on large scale.

The objective of grazing in the Oostvaardersplassen are

1. to keep grasslands suitable for grazing by geese (Anser anser L., A. albifrons L.);

2. to prevent shallow pools and ditches from being filled up with reed (Phragmites australis (Cav.) Trin. ex Steudel), so that they will remain suitable feeding sites for spoonbills (Platalea leucorodia L.) and herons (Ardea cinerea L., Egretta alba L.);

3. to change a reed dominated rough growth vegetation into a more open vegetation with patches of grasses, being a suitable hunting area for birds of prey ( $\mathrm{Cir}$ cus spec. L., Buteo spec. L., Falco tinnunculus L.).

In nature reserves, low stocking rates (less than one animal per $5 \mathrm{ha}$ ) are common. At such stocking rates, herbage is abundantly available, and is composed of several plant species. From this abundance the herbivores select a diet that meets their nutritional needs as much as possible. Often in this diet selection process, they make use of and affect some parts of their range intensively, others extensively or hardly at all (Duncan, 1983; Pratt et al., 1986; Putman, 1986). To obtain a better understanding of the effects of grazing on the vegetation and seasonal changes in feeding ecology, information on the nutritional value of forage plants is important. In this paper, the nutritional value of the main cattle forage plants in a high soil fertility landscape is discussed.

\section{Materials and methods}

\section{Study area}

Cattle and horse grazing has been applied in the Oostvaardersplassen since 1982. From 1982 to 1988 several Meuse-Rhine-IJssel and Friesian heifers and 1-21/2 year old Meuse-Rhine-IJssel and Scottish Highland bulls were involved from May to November. Winter data were only collected in 1982/1983 and 1983/1984. The animals lived in a small group (in winter time 4 animals, in summer time 8 animals) in a 20 ha study area. Each group of animals was replaced by a next group after 6 to 9 months.

The vegetation of the study area was dominated by reed Phragmites australis and Cirsium arvense (L.) Scop, with small amounts of Urtica dioica L., Poa trivialis L. 
and willows such as Salix alba L., Salix triandra (L.).

The diet consumed by the cattle was recorded by continuous bite counting (Hobbs et al., 1983) during the daylight period of observation days at frequencies of one day per week in winter and one to two days per month in summer. Forage samples were taken by the observer on the day following the observation day, simulating the bites by clipping and hand-plucking. No data could be collected from February to May because during this period animals consumed only the hay that was provided for their survival. The 68 observation days from all years were pooled into months or into four groups: spring (May-June), summer (July-mid September), autumn (mid September-end of November) and winter (December-February). The forage species were grouped into four classes: grasses, reed, forbs and browse.

\section{Analyses}

The forage samples were oven-dried at $70^{\circ} \mathrm{C}$ for 15 hours, followed by 1 hour at $105^{\circ} \mathrm{C}$ and milled with a $1 \mathrm{~mm}$ screen. Crude ash (CA), total Kjeldahl nitrogen (TKN) and neutral detergent fibre (NDF) using the Mould \& Robbins (1981a) method, were determined in all 260 forage samples. Crude protein (CP) was calculated by multiplying total Kjeldahl nitrogen by 6.25 . The in-vitro organic matter digestibility (IVOMD) was determined in all samples according to Tilley \& Terry (1963). Feed standards with known in-vivo digestible organic matter contents were used for the conversion of the in-vitro results to estimated in-vivo OMD. These standards covered a range from $16 \%$ to $85 \%$ OMD. The mineral contents were determined in 50 selected forage samples. Methodologies applied are specified following:

- sodium (Na) and potassium (K) soluble in $\mathrm{HNO}_{3}$, flame photometrically;

- calcium (Ca) and magnesium $(\mathrm{Mg})$ soluble in HCL-trichloroacetic acid, atomic absorption spectrophotometrically (AAS);

- copper $(\mathrm{Cu})$ soluble in $\mathrm{H}_{2} \mathrm{SO}_{4}-\mathrm{HNO}_{3}-\mathrm{H}_{2} \mathrm{O}_{2}$, AAS;

- phosphorus (P) soluble in $\mathrm{H}_{2} \mathrm{SO}_{2}-\mathrm{H}_{2} \mathrm{O}_{2}$, spectrophotometrically;

- sulphur (S) soluble in $\mathrm{HNO}_{3}-\mathrm{HCLO}_{4}$, gravimetrically;

- molybdenum (Mo) soluble in $\mathrm{H}_{2} \mathrm{SO}_{4}-\mathrm{HNO}_{3}$, spectrophotometrically with kaliumsulfocyanide.

\section{Calculations}

Digestible organic matter (DOM) was calculated as follows:

$$
\mathrm{DOM}=\mathrm{DM} \times \mathrm{IVOMD} \times(1-0.001 \mathrm{CA})
$$

The DOM, CP and mineral contents of the forage classes were related to maintenance requirements for energy and nutrients. The maintenance requirement levels for minerals were taken from NRLO (1973), ARC (1980) and van Soest (1982). The maintenance requirement for energy and $\mathrm{CP}$ were considered to be met when DOM equals about $450 \mathrm{~g} \mathrm{~kg}^{-1} \mathrm{DM}$ and CP equals about $75 \mathrm{~g} \mathrm{~kg}^{-1} \mathrm{DM}$ (van Soest, 
Table 1. The assumed cattle maintenance requirements $\left(\mathrm{g} \mathrm{kg}^{-1} \mathrm{DM}\right)$ for energy and protein (van Soest, 1982; ARC, 1980) and minerals (NRLO, 1973; ARC, 1980; van Soest, 1982).

\begin{tabular}{|c|c|c|c|c|c|c|c|c|c|c|}
\hline & DOM & $\mathrm{CP}$ & $\mathrm{Na}$ & $\mathbf{K}$ & $\mathrm{Ca}$ & $\mathbf{P}$ & $\mathrm{Mg}$ & $\mathbf{S}$ & $\mathrm{Cu}$ & Mo \\
\hline Maintenance requirement & 450 & 75 & 0.75 & 6 & 2.5 & 2.2 & 1.7 & 2 & 0.005 & $<0.005$ \\
\hline
\end{tabular}

1982; ARC, 1980). The maintenance requirement levels are given in Table 1.

Statistical analysis was according to methods of Sokal \& Rohlf (1981).

\section{Results}

\section{Botanical diet composition}

The mean monthly diet composition obtained by averaging the 68 diets observed during the above mentioned 6 years, is given in Figure 1. At the beginning of July cattle switched abruptly from grass (Poa trivialis) to reed. The summer diet was completed with forbs such as Atriplex prostrata L., Sonchus arvensis L. and S. asper (L.Hill.) and in some years Urtica dioica. In autumn the cattle gradually switched back to grass (Poa trivialis) completing their diet with forbs e.g. rosettes of Carduus crispus L, Cirsium arvense, C. vulgare (Savi) Tenore and Urtica dioica. In winter Poa trivialis became depleted and the animals had to switch to mainly bush grass (Calamagrostis epigejos L.) and browse. The consumed browse were twigs of Salix

grass reed browse

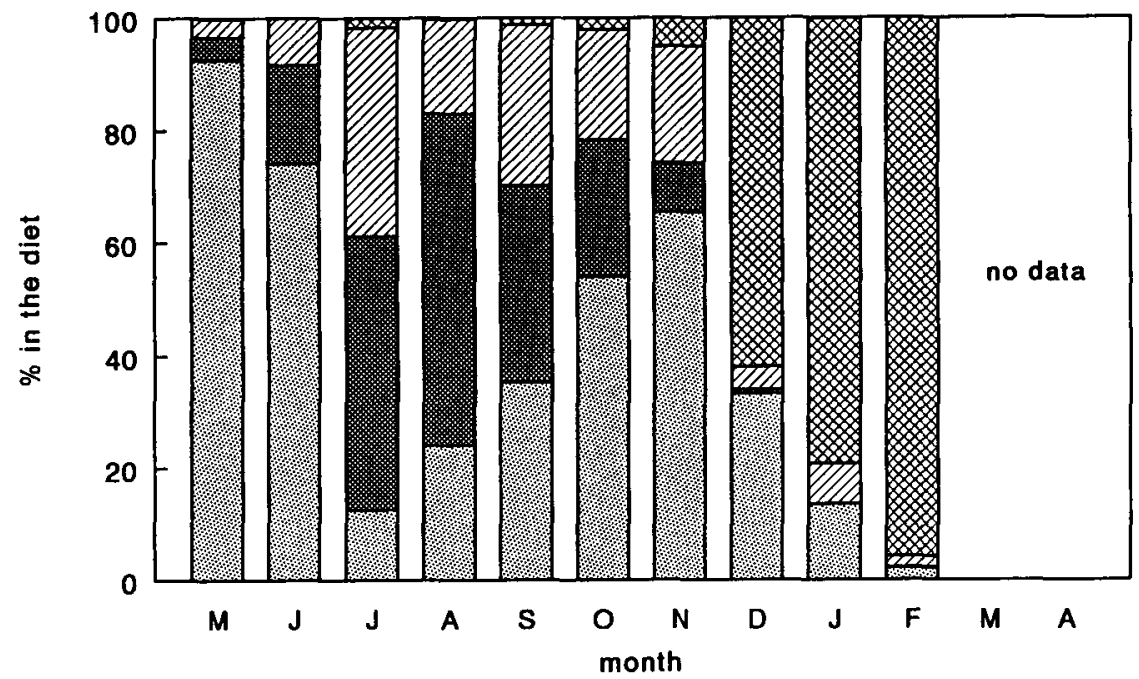

Figure 1. Botanical diet composition over the course of the year. 
alba, S. triandra, S. cinerea L., and some Sambucus nigra L. The forbs consisted of Urtica dioica and Galium aparine $\mathrm{L}$.

\section{Biochemical composition and digestibility}

There were clear general trends and seasonal differences in biochemical composition and digestibility of the various forage classes (Figs. 2a-d). In the winter period

GRASSES

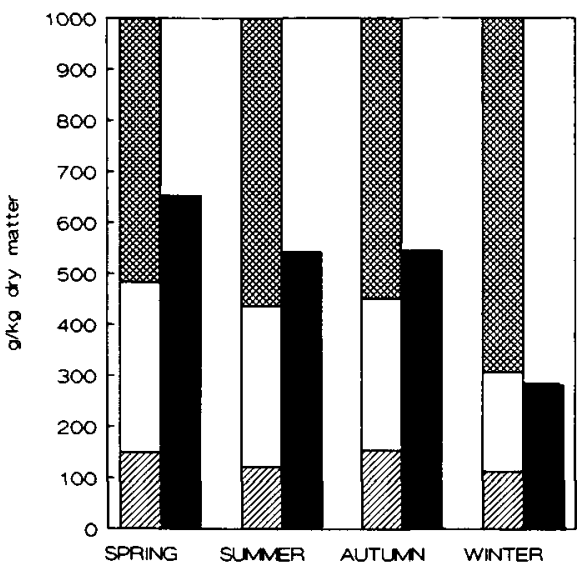

FORBS

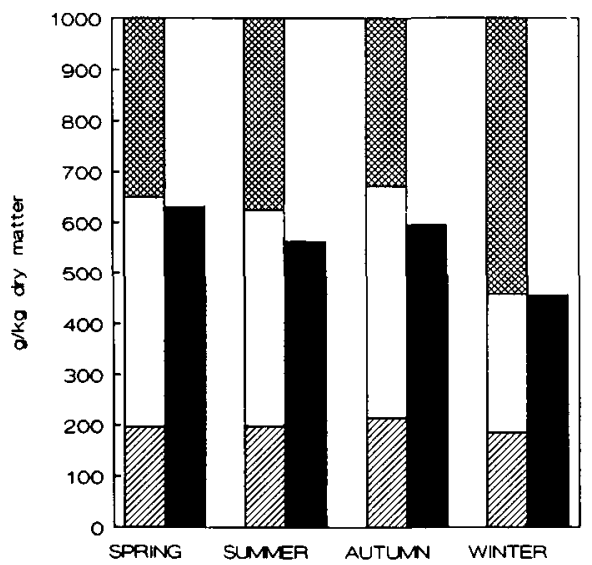

REED

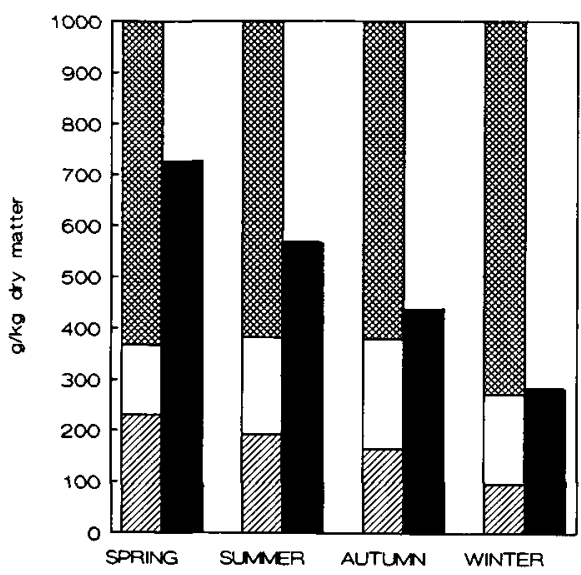

BROWSE

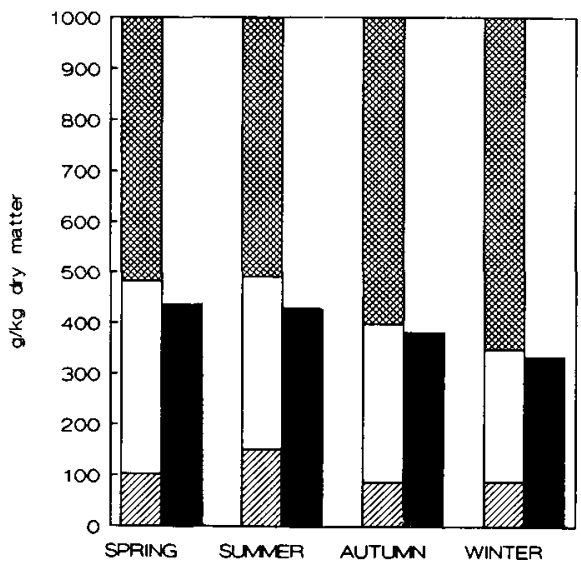

एWIS protein cell cont wall DOM

Figure 2. The chemical composition ( $\left.\mathrm{g} \mathrm{kg}^{-1} \mathrm{DM}\right)$ and the DOM content $\left(\mathrm{g} \mathrm{kg}^{-1} \mathrm{DM}\right)$ of grasses (a), reed (b), forbs (c) and browse (d). 


\section{J. T. VULINK AND H. J. DROST}

the cell wall content of the forage classes was at its highest and the CP and DOM content was at its lowest. CP content was lowest in browse in all seasons. Cell wall content was lowest in forbs and highest in reed. Despite the high cell wall content of reed, the $\mathrm{CP}$ and DOM contents were relatively high in spring and summer.

A comparison between the cell contents and DOM suggests an incomplete digestion of cell contents fraction in forbs (summer and autumn) and in browse (spring and summer).

The calculation of the digestibilities of cell contents (DCC in \% of DM) and cell walls (DCW in \% of DM) in relation to the apparent organic matter digestibility (DOM), however, requires the taking into account of the endogenous excretion $\mathrm{EE}$ (in $\mathrm{g} \mathrm{kg}^{-1}$ intake) as follows:

$$
\mathrm{DOM}=\mathrm{DCC} \times \mathrm{CC}+\mathrm{DCW} \times \mathrm{CW}-\mathrm{EE}
$$

(van Soest \& Moore, 1965)

where $\mathrm{CC}=$ cell content $\left(\mathrm{g} \mathrm{kg}^{-1} \mathrm{DM}\right)$ and $\mathrm{CW}=$ cell wall $\left(\mathrm{g} \mathrm{kg}^{-1} \mathrm{DM}\right)$.

Results were available for DOM, CW (= NDF, in $\left.\mathrm{g} \mathrm{kg}^{-1} \mathrm{DM}\right)$ and CC (= 1000$\mathrm{NDF}$, in $\mathrm{g} \mathrm{kg}^{-1} \mathrm{DM}$ ). No analysis data were available for $\mathrm{DCC}, \mathrm{DCW}$ and $\mathrm{EE}$. The endogenous excretion in our study may be expected to vary from ca 130 to ca $200 \mathrm{~g}$ $\mathrm{kg}^{-1} \mathrm{DM}$. This is caused by the variation among the involved feeds, ranging from highly digestible grasses to very coarse browse. (Deinum, 1974; Short \& Reagor, 1970; Robbins et al., 1975). The digestibility of the cell contents in 'normal' feeds is almost $100 \%$ (98 \% according to van Soest, 1967; Short \& Reagor, 1970).

The calculated DCW (assuming DCC $=98 \%$ and EE = ranging from 130 to 200 $\mathrm{g} \mathrm{kg}^{-1} \mathrm{DM}$ ) for forbs (summer, autumn) and browse (spring, summer) ranged 14$44 \%$, which are acceptable values.

\section{The relation to cattle maintenance requirement levels}

To compare the DOM content of the different forage classes with the assumed cat-

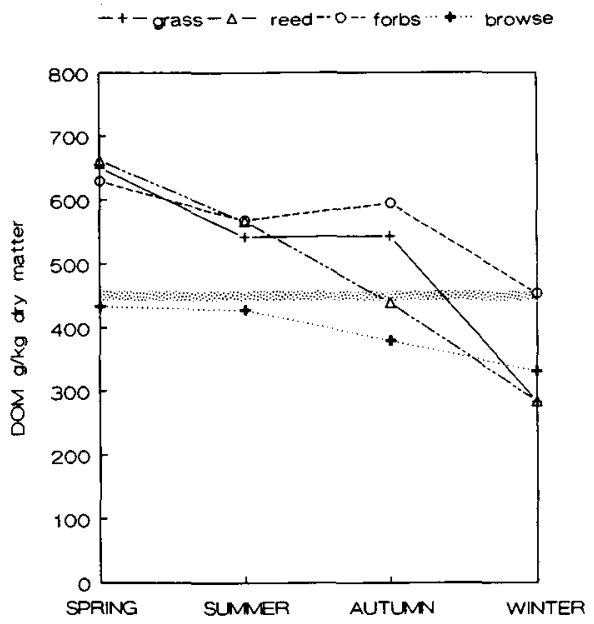

Figure 3. The general trends of average DOM content of grasses, reed, forbs and browse. The horizontal line gives the assumed cattle maintenance level for energy (450 $\mathrm{g} \mathrm{DOM} \mathrm{kg}^{-1}$ dry matter). 
tle maintenance requirements for energy, the DOM contents from figures $2 a-d$ are summarized in Figure 3. The level of $450 \mathrm{~g} \mathrm{~kg}^{-1} \mathrm{DM}$ content (cattle maintenance level for energy) however was reached at different times for the different classes. The DOM content of grasses was below maintenance level in winter, of reed in autumn and winter and of browse during the entire year. On the contrary, the DOM content of forbs exceeded maintenance level during the entire year.

When maturation of grass $P$. trivialis was restrained by grazing, the DOM level remained more constant (about $600 \mathrm{~g} \mathrm{~kg}^{-1} \mathrm{DM}$ ) during the whole year (Figure 4a).

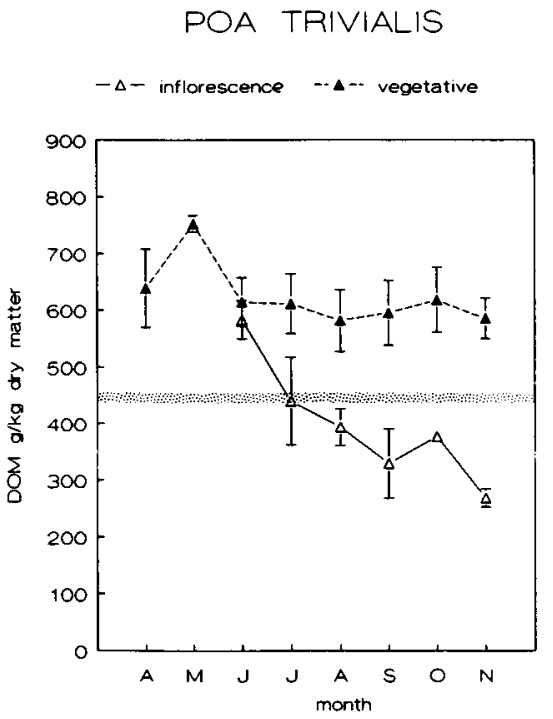

URTICA DIOICA

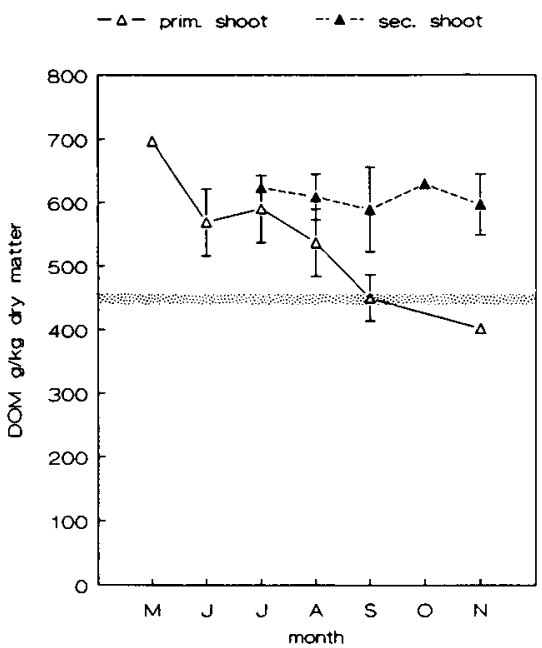

PHRAGMITES AUSTRALIS

$-\Delta-$ prim. shoot $\quad-\Delta-\cdot$ sec. shoot

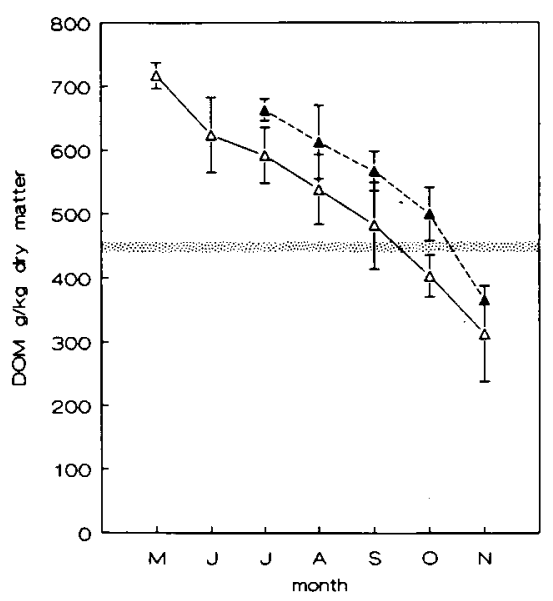

Figure 4. The average DOM content $( \pm$ s.d.) of Poa trivialis inflorescence and vegetative (a), reed primary and secundary shoots (b) and Urtica dioica primary and secundary shoots (c) over the course of the year. The horizontal lines are the assumed cattle maintenance levels for energy $(450 \mathrm{~g}$ DOM kg ${ }^{-1}$ dry matter). 
In reed and Urtica dioica grazing also stimulated regrowth, thus increasing DOM (Figure $4 \mathrm{~b}, \mathrm{c}$ ). In the grazed reed stands many primary shoots produced thin secondary shoots from lateral buds, especially when their apical meristem was damaged (van Deursen \& Drost, 1990). Urtica dioica produced secondary shoots too, when the top of the primary shoot was grazed.

The CP content of the four forage classes were above the maintenance level $(75 \mathrm{~g}$ $\left.\mathrm{kg}^{-1} \mathrm{DM}\right)$ the whole year, even in the winter period for grasses $\left(113 \mathrm{~g} \mathrm{~kg}^{-1} \mathrm{DM}\right)$, reed $\left(97 \mathrm{~g} \mathrm{~kg}^{-1} \mathrm{DM}\right)$, forbs $\left(185 \mathrm{~g} \mathrm{~kg}^{-1} \mathrm{DM}\right)$ and browse $\left(89 \mathrm{~g} \mathrm{~kg}^{-1} \mathrm{DM}\right)$.

The $\mathrm{K}, \mathrm{Ca}, \mathrm{P}, \mathrm{Cu}$ content of grasses, reed, forbs and browse exceeded the assumed cattle maintenance level during the entire year. In forbs these were highest, about two to three times the cattle maintenance levels. The Mo content of the forage classes was the whole year below $2 \mathrm{mg} \mathrm{kg}^{-1} \mathrm{DM}$. The $\mathrm{Na}$ and $\mathrm{Mg}$ content were marginal in some forage classes. In grasses and reed the $\mathrm{Na}$ content was below cattle maintenance level during the whole year. In browse the Na content reached the cattle maintenance level only in summer. In forbs the Na content was 5 to 10 times cattle maintenance level in spring and summer and decreased to cattle maintenance level in autumn and winter. The $\mathrm{Mg}$ content of reed was below maintenance level the whole year, of grasses in spring and winter and of browse only in winter. The $\mathrm{Mg}$ content of forbs was two to three times the maintenance level the whole year.

\section{Discussion and conclusion}

Willow twigs may contain about $12 \%$ phenolic compounds and $1 \%$ tannins (Mould \& Robbins, 1981a). The digestibility of the cell contents in browse may considerably be lower than $100 \%$ through the action of phenolic compounds (McLeod, 1974; Mould \& Robbins, 1981b; Robbins et al., 1987a; Robbins et al., 1987b). Our results, however, show no indication for a decreased cell content digestibility.

Among the micro minerals only $\mathrm{Cu}$ and Mo were determined, because a $\mathrm{Cu}$ deficiency may occur on marine sediments through a Cu:Mo complex $\left(\mathrm{Cu} \times \mathrm{Mo} \times \mathrm{SO}_{4}\right)$ of low solubility depressing Cu absorption (Matrone, 1970; ARC, 1980). The Mo concentration in the forage classes were safely below the levels of $5 \mathrm{mg} \mathrm{kg}^{-1} \mathrm{DM}$ for cattle (Miller et al., 1970; ARC, 1980). The macro minerals Na and Mg may be insufficient in periods when cattle select only grass or reed. Some forbs in the diet however will solve this problem; forbs are an important mineral source.

The seasonal changes in biochemical composition and digestibility are also found in other studies (Short et al., 1974; Chapin et al., 1986; Coppock et al., 1986; Gordon, 1989). As the plant matures, the cell-wall constituents increase and the DOM content decreases. The low DOM content of grasses and forbs in winter in our study is not only caused by maturation but also by a change in species composition within the forage classes. The relatively low DOM content of Calamagrostis epigejos determined the low DOM content of grasses in winter.

The results in Figure 2 may be directly compared with English results (Gordon, 1989). However, in this comparison has to be taken into account that our DOM contents are based upon direct in vitro analyses, whereas the other study presents 
assumed DOM contents, calculated from biochemical composition of the feeds. The cell wall has been determined with the same method in both studies. The results show a rather good agreement in this parameter. DOM contents are consistently lower in our study than in the other. In spring, summer and autumn the mean difference is ca $110 \mathrm{~g} \mathrm{~kg}^{-1} \mathrm{DM}$ with a standard error (s.e.) of $16 \mathrm{~g} \mathrm{~kg}^{-1} \mathrm{DM}$. In winter however the mean difference amounts to ca $250 \mathrm{~g} \mathrm{~kg}^{-1} \mathrm{DM}$ with s.e. $29 \mathrm{~g}$ $\mathrm{kg}^{-1} \mathrm{DM}$. This suggests methodological differences (spring-autumn) but also significant differences in winter feed quality.

In another publication (Vulink \& Drost, 1992) we presented evidence in favour of the hypothesis that cattle diet selection is governed mainly by the objective of maximum energy intake, at least in the eutrophic conditions of our study area. Starting with this hypothesis, the comparison with Gordons (1989) results suggests that mesotrophic and oligotrophic conditions result in habitats that are more suitable for cattle grazing in winter than our (Poa-Phragmites) eutrophic habitat.

\section{Acknowledgements}

We thank J. Diender, A. Smit and A. Muis for assistance in the field, W. Eenkhoorn for assistance with analysing the data.

\section{References}

Agricultural Research Council (ARC), 1980. The nutrient requirements of ruminant live stock. Commonwealth Agricultural Bureaux, London, $351 \mathrm{pp}$.

Chapin, F. S., J. D. McKendrick \& D. A. Johnson, 1986. Seasonal changes in carbon fractions in Alaskan tundra plants of differing growth form: implications for herbivory. Journal of Ecology 74: 707731.

Coppock, D. L., D. M. Swift \& J. E. Ellisa, 1986. Seasonal nutritional characteristics of live stock diets in a nomadic pastoral ecosystem. Journal of Applied Ecology 23: 585-595.

Deinum, B., 1974. Structural inhibitors of quality in forage. Växtodling 28: 42-51.

Deursen, E. J. M. van \& H. J. Drost, 1990. Defoliation and treading by cattle of reed Phragmites australis. Journal of Applied Ecology 27: 284-297.

Duncan, P., 1983. Determinants of the use of habitat of horses in a Mediterranean Wetland. Journal of Animal Ecology 52: 93-109.

Gordon, I. J., 1989. Vegetation community selection by ungulates on the isle of Rhum. I. Food Supply. Journal of Applied Ecology 26: 35-51.

Hobbs, N. T., D. L. Bakker \& R. B. Gill, 1983. Comparative nutritional ecology of montane ungulates during winter. Journal of Wildlife Management 47: 1-16.

Matrone, G., 1970. Studies on copper-molybdenum-sulphate interrelationships. In: C. F. Mills (Ed.), Trace elements metabolism in animals, p. 354-362. E. \& S. Livingstone, Edinburgh, London.

McLeod, M. N., 1974. Plant tannins. Their role in forage quality. Nutrition Abstracts and Reviews 44: 803-815.

Miller, L. R., A. L. Lesperance, V. R. Bohman \& E. H. Jensen, 1970. Toxicity of inorganic and organic forms of molybdenum to the bovine. Journal of Animal Science 30: 1032-1033.

Mould, E. D. \& C. T. Robbins, 1981a. Evaluation of detergent analysis in estimating nutritional value of browse. Journal of Wildlife Management 45: 937-947.

Mould, E. D. \& C. T. Robbins, 1981b. Nitrogen metabolism in elk. Journal of Wildlife Management 45: 323-334.

NRLO, 1973. Tracing and treating mineral disorders in cattle. Pudoc, Wageningen, Netherlands, 61 pp. 
Pratt, R. M., R. J. Putman, J. R. Ekins \& P. J. Edwards, 1986. Use of habitat of free ranging cattle and ponies in the New Forest, Southern England. Journal of Applied Ecology 23: 539-557.

Putman, R. L., 1986. Grazing in temperate ecosystems. Large herbivores and the ecology of the new forest. Croom Helm, London, $210 \mathrm{pp}$.

Robbins, C. T., P. J. van Soest, W. W. Mautz \& A. N. Moen, 1975. Feed analyses and digestion with reference to white-tailed deer. Journal of Wildlife Management 39: 67-79.

Robbins, C. T., S. Mole, T. A. Hagerman \& T. A. Hanley, 1987a. Role of tannins in defending plants against ruminants: reduction in dry matter digestion? Ecology 68: 1606-1615.

Robbins, C. T., T. A. Hanley, A. E. Hagerman, O. Hjeljord, D. L. Baker, C. C. Schwartz \& W. W. Mautz, 1987b. Role of tannins in defending plants against ruminants: reduction in protein availability. Ecology 68: 98-107.

Short, H. L. \& J. C. Reagor, 1970. Cell wall digestibility affects forage value of woody twigs. Journal of Wildlife Management 34: 964-967.

Short, H. L., R. M. Blair \& C. A. Segelquist, 1974. Fibre composition and forage digestibility by small ruminants. Journal of Wildlife Management 38: 197-209.

Soest, P. J. van, 1967. Development of a comprehensive system of feed analyses and its application to forages. Journal of Animal Science 26: 119-128.

Soest, P. J. van, 1982. Nutritional Ecology of the Ruminant. O and B Books, Oregon, $374 \mathrm{pp}$.

Soest, P. J. van \& L. A. Moore, 1965. New chemical methods for analysis of forages for the purpose of predicting nutritive value. In: Proceedings 9th International Grassland Congress Sao Paulo, Brazil, p. 783-789.

Sokal, R. R. \& F. J. Rohlf, 1981. Biometry. Second edition. Freeman \& Company, New York, 859 pp.

Tilley, J. M. \& R. A. Terry, 1963. A two stage technique for the in-vitro digestion of forage crops. Journal of the British Grassland Society 18: 104-111.

Vulink, J. T. \& H. J. Drost, 1992. A causal analysis of diet composition in free ranging cattle in reeddominated vegetation. Oecologia (In press). 